\title{
удк[37.015.3+613.8]:[271.2:050.9](477.85),,186/191"
}

Сергій Дарійчук

Чернівецький національний університет імені Юрія Федьковича

ORCID ID 0000-0001-889-1293

DOI 10.24139/2312-5993/2020.10/339-347

\section{ФІЗИЧНЕ ВИХОВАННЯ ДІТЕЙ ТА МОЛОДІ НА СТОРІНКАХ СУЧАСНИХ ГАЗЕТ ЧЕРНІВЕЦЬКОЇ ОБЛАСТІ}

Задля творчого використання досвіду висвітлення фізичного виховання дітей та молоді в пресі Буковини з'ясовано фактичний стан публікачій у газетах Чернівецької області. Мета дослідження - проаналізувати статті в сучасних газетах Чернівецької області задля визначення відповідності публікацій на фізкультурно-спортивну тематику зацікавленням населення краю, для чого застосовано комплекс методів: загальнонаукові; конкретно-наукові; логікосистемний аналіз; емпіричні. Розглянуто три групи газет - районні, народознавчі та обласне учнівське видання й виокремлені основні напрями фізкультурно-спортивної тематики: результати змагань із різних видів спорту та успіхи місцевих спортсменів («Дністрові зорі», «Хотинські вісті», «Вижницькі обрії», «Учнівський вісник Буковини»); популяризація фрізичної активності та здорового способу життя («Голос краю», «Сокиряни. Сім днів», «Хотинські вісті», «Економічно-благочестивий вісник», «Доброго здоров'я!» та «Добрий порадник»).

Ключові слова: Буковина, газета, діти, здоровий спосіб життя, тематика, фізичне виховання, школярі.

Постановка проблеми. На часі $€$ потреба переосмислення сутності й вагомості презентації аспектів фізичного виховання і спорту в сучасних засобах масової інформації, модернізації впливу преси на дітей та молодь відповідно до сучасних викликів, розробки й апробації системного, ретельно вивіреного, науково обґрунтованого і довготермінового плану дій, результати якого стануть відчутні в перспективі. Задля творчого використання досвіду висвітлення фізичного виховання дітей та молоді в українській пресі Буковини (другої половини XIX - початку XX ст.) і презентації рекомендацій щодо систематичності, тематичності та змістовності матеріалів на визначену тему в сучасних засобах масової інформації необхідно з'ясувати фактичний стан наявності та якості таких публікацій у газетах та періодичних друкованих виданнях Чернівецької області.

Аналіз актуальних досліджень. Ґенеза висвітлення проблем фізичного виховання в засобах масової інформації як повноцінної складової системи пропаганди, становлення преси як ефективного інструменту вирішення завдань розвитку галузі фізичної культури і спорту, фізичного виховання розглянути низкою науковців (А.Гусєв, С. Кость, Ю. Сазонова, І. Свістельник) (Гусєв, 2016; Сазонова, 2017; Свінціцький, 
2013; Тумак, 2012). Популяризації фізичного виховання в контексті діяльності громадських товариств, зокрема студентських та фізкультурноспортивних, присвячені роботи М. Кожокар, Ю. Тумак (Кожокар, 2018; Тумак, 2012), впливу преси на громадське усвідомлення потреби фізичної активності - Н. Гнесь, Т. Завгородньої, І. Стражнікової, О. Цибанюк (Гнесь, 2007; Завгородня та Стражнікова, 2016; Цибанюк, 2008).

Мета дослідження - проаналізувати статті в сучасних газетах Чернівецької області задля визначення відповідності публікацій на фізкультурно-спортивну тематику зацікавленням населення краю.

Методи дослідження. Для досягнення мети та реалізації поставлених завдань застосовано комплекс методів: загальнонаукових (аналіз, синтез, абстрагування та конкретизація, систематизація, класифікація, періодизація, узагальнення й інтерпретація); конкретнонаукових: метод термінологічного аналізу (сприяв актуалізації сутності базових понять та встановленню їхнього системного підпорядкування); логіко-системний аналіз значного масиву нормативних актів, наукових публікацій (було застосовано задля виявлення й систематизації фактологічного матеріалу); історико-системний метод (використано для створення цілісної картини висвітлення проблем фізичного виховання дітей та молоді на сторінках преси краю); емпіричні.

Виклад основного матеріалу. Задля аналізу відповідності публікацій на фізкультурно-спортивну тематику зацікавленням населення краю ми проаналізували назви, вихідні данні та зміст видань Чернівецької області, інформацію про які нами знайдено на сайті http://www.ukrbook.net/ (Газети, журнали. Чернівецька область).

Із загального числа ми виокремили низку видань, які апріорі не розглядали проблеми фізичного виховання підростаючого покоління («На варті закону» і «На варті закону. Глибока»; «M eleag natal (Рідний край)», «Новий день» («M onitorul de Hliboca»)», «Gazeta Polska Bukowiny» «Хесед Шушана») тощо. Науково-популярна газета «Медична фізика, техніка та інформатика», що видається без чіткої періодичності, і $\epsilon$ спільним проєктом кафедри біологічної фізики та медичної інформатики Буковинського державного медичного університету та кафедри медичної фізики діагностичного та лікувального обладнання Тернопільського державного медичного університету ім. І.Я.Горбачевського. Метою газети стало висвітлення новітньої інформації в таких наукових напрямах, як медична та біологічна фізика, медична техніка та апаратура, медична інформатика та біостатистика, та обмін досвідом наукової роботи між 
вищими навчальними закладами України (Веб-сайт). Видання рекламного або чітко визначеного інформаційного характеру - «РіоЧернівці», газета приватних оголошень; «Ва-Банк», «Від і до», ділове видавництво Буковини та «Телетиждень» (програма телебачення, анонси та гороскоп, оголошення та реклама), нами не аналізувались.

Крім того, певна кількість 3МІ Чернівецької області на даному етапі або припинили свою діяльність, або знаходяться в стані реорганізації (газета «Рідний край» м. Сторожинець) (Редакція газети Рідний край).

Отже, всього серед засобів масової інформації сучасної Буковини нами вибрано 21 одиниці газет та друкованих видань. 3 метою визначення відповідності публікацій на фізкультурно-спортивну тематику запитам населення краю розглянемо три групи засобів масової інформації районні газети; народознавчі видання та обласну учнівську газету.

Окремої уваги заслуговують видання, редакція та основний читач яких знаходиться не тільки в обласному центрі, а й у районах Чернівецької області. Це «Вижницькі обрії» (м. Вижниця), «Голос краю» (м. Заставна), «Дністрові зорі», «Сокиряни. Сім днів» (м. Сокирянщини), «Карпати» (смт. Путила), «Наша газета» (м. Новодністровськ), «Новий день» (смт. Глибока), «Рідне слово» (смт. Кельменці), «Рідний край» (м. Сторожинець), «Хотинські вісті» (м. Хотин) та інші.

Характерними рисами цих видань визначаємо тривалий час існування із певною кількістю змін назви - газета «Вижницькі обрії» була заснована 1945 року як районна газета із назвою «Верховина», згодом змінила назву на «Радянська Верховина» («Дністрові зорі» 1965 р.; «Карпати» 1941 р.); значний об'єм цих видань - 8-12 сторінок, спричинений політикою редакції: тут знаходять постійне місце матеріали про діяльність державної, обласної і районної влади, досягнення краю в галузі освіти, культури, медицини, боротьби з наслідками надзвичайних ситуацій, соціально-економічного розвитку Буковини й регіонів зокрема, нариси і зарисовки про людей, які $є$ гордістю краю, природоохоронна тематика тощо. Це справжні «літописи краю», де кожна подія знаходила і знаходить своє місце в газеті, і тому легко простежується життя району, що радувало й турбувало людей у той чи інший період. Саме тому впливовість цих 3Мl не можливо не визнавати (Газета «Вижницькі обрії»; Дністрові зорі. Засоби масової інформачії Чернівецької області; Редакція газети Рідний край).

Аналіз матеріалів, надрукованих на сторінках таких видань (див. табл. 1), дозволив виокремити основні напрями фізкультурно-спортивної тематики та констатувати, що значна кількість статей присвячена: 
результатам змагань із різних видів спорту (футбол, легка атлетика, боротьба, волейбол, туризм тощо) регіонального, всеукраїнського та міжнародного рівнів та успіхам місцевих спортсменів («Дністрові зорі», «Хотинські вісті», «Вижницькі обрії»); історії спортивного руху та/або спогадам відомих місцевих тренерів («Карпати»); проблемам популяризації фізичної активності та здорового способу життя («Голос краю», «Сокиряни. Сім днів», «Наша газета», «Новий день», «Хотинські вісті»).

Ще однією особливістю таких статей стало виокремлення та активне «розкручування» одного чи групи видів спорту, що популярні в тому чи іншому населеному пункті Чернівецької області: м. Хотин - гандбол та боротьба; м. Сторожинець - волейбол, легка атлетика; м. Новоселиця боротьба, волейбол; м. Заставна - футбол, вільна боротьба, жіночий гандбол; м. Новодністровськ - гребля, футзал, баскетбол тощо. Популярність же певного виду пов'язана із наявністю дитячо-юнацької спортивної школи або спортивного клубу та тренерсько-викладацького складу в населеному пункті, історичних традицій регіону та сформованої матеріально-технічної бази стадіону, спортивного залу та майданчиків тощо. Але рубрики «Фізична культура і спорт», «Краса тіла» або «Здоров'я» в цих виданнях або об'єднані в загальній «Спорт», або не є постійними, а скоріше епізодичними.

Таблиця 1

Перелік матеріалів щодо проблем фізичного виховання населення краю, зокрема дітей та молоді, на сторінках районних газет Чернівецької

області

\begin{tabular}{|c|c|c|}
\hline & $\begin{array}{l}\text { Назва та вихідні дані } \\
\text { видання }\end{array}$ & Автор, назва публікації, коротка анотація \\
\hline 1. & Карпати. 10 грудня 2020 & Чемпіонат світу з футболу 1966. Сторінки історії \\
\hline 2. & $\begin{array}{l}\text { Вижницькі обрії. } 2004.10 \\
\text { вересня (№ 37). С. } 6\end{array}$ & Фізичне виховання учнів - пріорітет освіти \\
\hline 3. & $\begin{array}{l}\text { Вижницькі обрії. 2004. } 24 \\
\text { вересня (№ 39). С. } 5\end{array}$ & Вижниччина приваблює туристів \\
\hline 4. & $\begin{array}{l}\text { Вижницькі обрії. } 2005.8 \\
\text { квітня (№ 15). С. } 2\end{array}$ & «Зеленому туризму» - зелене світло \\
\hline 5. & $\begin{array}{l}\text { Вижницькі обрії. 2006. } 14 \\
\text { квітня (№ 16). С. } 5\end{array}$ & $\begin{array}{l}\text { Мельничук Л. Змагаються бюджетники. } \\
\text { Спартакіада серед працівників бюджетних установ } \\
\text { та організацій у Вижниці }\end{array}$ \\
\hline 6. & $\begin{array}{l}\text { Вижницькі обрії. 2006. } 12 \\
\text { травня (№ 20). С. } 6\end{array}$ & $\begin{array}{l}\text { МельничукЛ. Досвід імолодість. } \\
\text { Про зональні змагання першості Чернівецької } \\
\text { області з шахів серед ветеранів і молоді на призи } \\
\text { М. Пилипенка }\end{array}$ \\
\hline 7. & $\begin{array}{l}\text { Буковинський вісник. } 2004 . \\
4 \text { червня (№2). С.19. }\end{array}$ & $\begin{array}{l}\text { Мельничук Л. } 3 \text { династії борців. } \\
\text { Про майстра спорту вільної боротьби з Вижниці } \\
\text { Ф. Фока }\end{array}$ \\
\hline
\end{tabular}




\begin{tabular}{|l|lll|l|}
\hline 8. & $\begin{array}{l}\text { Хотинські } \\
\text { 2020. С. } 4\end{array}$ & вісті. 14 січня & М. Шевчук. Футзальні змагання \\
\hline 9. & $\begin{array}{l}\text { Хотинські вісті. 29 січня } \\
\text { 2020. С. } 4\end{array}$ & $\begin{array}{l}\text { Історії людей, які вражають і надихають. } \\
\text { Про складний шлях спортсменів В. Берника та І. } \\
\text { Подрі до звання «Майсет спорту України» }\end{array}$ \\
\hline 10. & $\begin{array}{l}\text { Голос краю. 19 вересня } \\
\text { 2016. С. } 4\end{array}$ & $\begin{array}{l}\text { Ткач У. Олімпійський тиждень - у Заставнівській } \\
\text { гімназії }\end{array}$ \\
\hline 11. & $\begin{array}{l}\text { Голос краю. 26 вересня } \\
\text { 2015. С. 3 }\end{array}$ & $\begin{array}{l}\text { Мельниченко Н. Відбулася спартакіада «Сила духу» } \\
\text { В програму спартакіади серед інвалідів праці, в якій } \\
\text { брали участь спортсмени з Заставнинщни, входили } \\
\text { армспорт, бомбаскет, гирьовий спорт, дартс, теніс і } \\
\text { шахи }\end{array}$ \\
\hline 12. & $\begin{array}{l}\text { Новий день. 03.02.2020. } \\
\text { С. } 4\end{array}$ & $\begin{array}{l}\text { Мешканець селища Глибока Андрій Челеняк } \\
\text { отримав виклик у збірну України з волейболу U17 }\end{array}$ \\
\hline
\end{tabular}

Ще однією специфічною групою засобів масової інформації сучасної Буковини, що у своєму змісті розглядають проблеми фізичного виховання дітей та молоді виокремлюємо «Економічно-благочестивий вісник. Народознавча газета Гарафіни Маковій», газети «Доброго здоров'я!» та «Добрий порадник». Фізичне виховання підростаючого покоління загартування організму, гармонійний розвиток форм, функцій і фізичних можливостей людини, формування життєво важливих рухових навичок та вмінь і зміцнення здоров'я розглядаються в цих виданнях крізь призму народних звичаїв, обрядів у повсякденному житті як засіб збереження української ідентичності. Опубліковані матеріали стверджували про необхідність виховання етнічної своєрідності через естетику рухів, загартування та гігієнічні навички; формування моральних цінностей та «здорової» ментальності: «Обман, підлість, брехня, що шкодить нам і нашим нащадкам», «Вправи та ігри для тіла і духу», «Плітки, покару отримує не той, хто складає, а хто сприймає і розносить», «Нетверезий спосіб життя», «Куриво, наркоманія» (Економічно-благочестивий вісник Гарафіни Маковій); «Спорт чи фізкультура», «Правила загартування» («Доброго здоров'я!»). Але ігрова діяльність дітей та молоді в цих виданнях пов'язується з постійною трансформацією обрядових дійств, лише як складова, зокрема звичаїв українського весілля або хрестин, святкування «Зелених свят» або «Івана Купала» (Маковій, 2019а; 20196; 2019в).

Ще одним специфічним ЗМІ Чернівецької області визначаємо «Учнівський вісник Буковини» - обласну газету для школярів, що в державних звітних документах фіксується як «друкований». Проте, нами знайдено лише ії електронну версію. За задумом, ця газета об'єднує всіх школярів регіону, тут кожен учень може публікувати власні статті, твори, 
інтерв'ю, представляти проєкти тощо. Серед рубрик віснику, а їх 15 (серед яких «Шкільне життя», «Учнівська еліта», «Моя позиція», «Відомі постаті», «Творимо майбутнє», «Екологія», «ЗНО», «Олімпіади» тощо), ми знаходимо «Здоровий спосіб життя». Саме ця рубрика об'єднала всі матеріали на загальну тему «Фізичне виховання дітей та молоді. Спорт та здоровий стиль життя». Аналіз змісту статей дозволив нам розділити їх на три великі загальні тематичні напрями: успіхи спортсменів Чернівецької області на змаганнях (Волейболістки Чернівецької обласної ДЮСШ братимуть участь в Чемпіонаті України з волейболу «Дитяча ліга» у Полтаві; 12 нагород вибороли вихованці обласної ДЮСШ на відкритому чемпіонаті з вільної боротьби; Нові успіхи чернівецьких борчинь Соломії та Марії Винник на всеукраїнському турнірі 3 вільної боротьби; волейболістки Чернівецької обласної ДЮСШ кращі в області! Подвійне срібло тенісистів Чернівецького професійного ліцею сфери послуг; Нові успіхи борців Чернівецької обласної ДЮСШ; Завершився національних юнацький турнір з тенісу на призи зимових канікул); аспекти організації оздоровчих та фізкультурно-масових заходів у закладах освіти регіону (Вихованці Борівського ЗНЗ пропагують здоровий спосіб життя; У Лужанському ЗНЗ І-ІІ ступенів імені В. Орелецького проведено тиждень за здоровий спосіб життя та безпеки дорожнього руху; Чудейська ЗОШ I-II ступенів №3: здоров'я важливе! В Брусницький ЗНЗ провели брейн-ринг, анкетування, конкурси на кращі ребуси, трансляції фільмів; Олімпійський тиждень у Вікнянській школі; У Сокирянському вищому професійному училищі пропагують здоровий спосіб життя); особливості здорового харчування дітей шкільного віку (Яким повинен бути сніданок школяра? обід школяра у різних країнах світу! Бери участь у опитуванні; Стали відомі результати анонімного тестування серед буковинських учнів «Сніданок школяра») (Учнівський вісник Буковини).

Висновки та перспективи подальших наукових розвідок. Отже, увага сучасних школярів регіону прикута до трьох потужних напрямів: розвитку певних видів спорту - боротьба, волейбол та теніс та результатів їх однолітків у змаганнях всеукраїнського рівня, проблемі організації у стінах школи якісного та здорового харчування й публікацій певного «звітного» характеру про проведені заходи в школах Чернівецької області. Жодної об'яви про спортивні гуртки та секції із запрошенням на тренування від тренерів та вчителів, анонсу фізкультурно-спортивного заходу для дітей та молоді; статті про необхідність та користь занять фізичною культурою і спортом або нових, сучасних видів фізичної активності нами не знайдено. Крім того, популярність електронної газети серед школярів регіону досить низька, про що свідчить 
відвідуваність сайту - 14 переглядів за тиждень; і ці перегляди здебільшого стосувались $3 \mathrm{HO}$ або Олімпіад школярів.

\section{ЛITЕРАТУРА}

Газета «Вижницькі обрії» веб-сайт. Режим доступу: http://vnrda.gov.ua/index.php/komunalni-zmi-rayonu/215-raionna-hazeta-

vyzhnytski-obrii. (Newspaper "Vyzhnytskyi Horizons" website. Retrieved from: http://vnrda.gov.ua/index.php/komunalni-zmi-rayonu/215-raionna-hazetavyzhnytski-obrii).

Газети, журнали. Чернівецька область. Веб-сайт. Режим доступу: http://www.ukrbook.net/DZMI obl 2/Cherniv obl/Cherniv.htm (Дата звернення 26.11.2020). (Newspapers, magazines. Chernivtsi region. Website Retrieved from: http://www.ukrbook.net/DZM I obl 2/Cherniv obl/Cherniv.htm).

Гнесь, Н. А. (2007). Становлення і розвиток фрізичного виховання учнів народних школах Буковини (1869-1918) (автореф. дис. ... канд. пед. наук: спец. 13.00.01). Івано-Франківськ (Hnes, N. А. (2007). Formation and development of physical education of students of public schools of Bukovina (1869-1918). (PhD thesis abstract). Ivano-Frankivsk).

Гусєв, А. В. (2016). Історія та функціонально-типологічні особливості спортивної медіакомунікації. Дніпропетровськ (Husev, A. V. (2016). History and functionaltypological features of sports media communication. Dnipropetrovsk).

Дністрові зорі. Засоби масової інформації Чернівецької області (1996). Чернівці (Dniester stars. Mass media of Chernivtsi region (1996). Chernivtsi).

Завгородня, Т. К., Стражнікова, І. В. (2016) Стан дослідженості ролі громадських організацій Західного регіону України у розвитку теорії і практики виховання. Особистість, суспільство, політика: матер. III Міжнар. наук.-практ. конф., Люблін, 4. 2, (сc. 36-38) (Zavhorodnia, T. K., Strazhnikova, I. V. (2016). The state of research on the role of public organizations in the Western region of Ukraine in the development of theory and practice of education. Personality, society, politics: mater. III International. scientific-practical conf., Lublin, Part 2, (рp. 36-38).

Кожокар, М. (2018). Історичні традиції виховання фізичної культури і здорового способу житя у часописах Буковини (друга половина XIX - початок XX століття). Мистецька освіта: зміст, технології, менеджмнт, 13, 110-119 (Kozhokar, M. (2018). Historical traditions of education of physical culture and healthy lifestyle in magazines of Bukovina (second half of the XIX - early XX century). Art education: content, technology, management, 13, 110-111).

Кость, С. (2008). Історія української журналістики (західноукраїнська преса першої половини XX cm.: структура, проблематика). Книга перша. Львів. (Kost, S. (2008). History of Ukrainian journalism (Western Ukrainian press of the first half of the XX century: structure, issues. Book one. Lviv).

Маковій, Г. (2019а). Вправи та ігри для тіла і духу. Економічно-благочестивий вісник, 3, 3-4 (M akovii, H. (2019a). Exercises and games for body and spirit. Economic and pious newsletter, 3, 3-4).

Маковій, Г. (2019б). Куриво, наркоманія. Економічно-благочестивий вісник, 3, (M akovii, H. (2019b). Smoking, drug addiction. Economic and pious newsletter, 3, 3-4).

Маковій, Г. (2019в). Не тверезий спосіб життя. Економічно-благочестивий вісник, 2 (M akovii, H. (2019). Not a sober lifestyle. Economic and pious newsletter, 2).

Редакція газети Рідний край. Веб-сайт. Режим доступу:
https://5140.0rg/company/255705-redakcziya-gazeti-ridnij-kraj (Editorial office of


Педагогічні науки: теорія, історія, інноваційні технології, 2020, № 10 (104)

the newspaper Native land. Website. Retrieved from:

https://5140.org/company/255705-redakcziya-gazeti-ridnij-kraj).

Сазонова, Ю. О. (2017). Зародження та формування київської спортивної преси (кінець XIX 1917 р.). Вісник ХДАК, 50, 263-274 (Sazonova, Yu. О. (2017). Origin and formation of the Kyiv sports press (late XIX - 1917). Bulletin of the KhSAC, 50, 263-274).

Свінціцький, А. (2013). Здоров'я населення як важливого чиннику державотворення та національної безпеки. Практикуючий лікар, 2, 7-13 (Svintsitskyi, A. (2013). Public health as an important factor in state formation and national security. Practitioner, 2, 7-13).

Свістельник, І. (2010). Книговидання та періодична преса у галузі фізичної культури і спорту. К.: Кондор (Svistelnyk, I. (2010). Book publishing and periodical press in the field of physical culture and sports. K.: Condor).

Тумак, Ю. І. (2012). Проблеми діяльності фізкультурно-спортивних товариств на сторінках преси Буковини австро-угорського періоду. Наук. вісник Ужгород. нац. ун-ту. Педагогіка. Соціальна робота, 25, 211-212 (Tumak, Yu. I. (2012). Problems of activity of physical culture and sports societies on the pages of the press of Bukovina of the Austro-Hungarian period. Science. Bulletin of Uzhhorod. nat. un-tu. Pedagogy. Social work, 25, 211-212).

Учнівський вісник Буковини. Веб-сайт. Режим доступу: https://schoollife.cv.ua/category/tvorymo-majbutnye-razom/zdorovyj-sposib-zhyttya/page/3/

(Student bulletin of Bukovyna. Website. Retrieved from: https://schoollife.cv.ua/ category/tvorymo-majbutnye-razom/zdorovyj-sposib-zhyttya/page/3/).

Цибанюк, О.О. (2008). Управління системою фізичного виховання школярів на Буковині (друга половина XIX - початок XX століття) (автореф. дис. ... канд. пед. наук: 13.00.01). Івано-Франківськ (Tsybaniuk, 0. 0. (2008). Management of the system of physical education of schoolchildren in Bukovyna (second half of the XIX beginning of the XX century) (PhD thesis abstract). Ivano-Frankivsk).

Веб-сайm (Website). Retrieved from: https://www.bsmu.edu.ua/actual events/4906gazeta-medychna-fizyka-tehnika-informatyka/.

\section{PEЗЮME}

Дарийчук Сергей. Физическое воспитание детей и молодежи на страницах современных газет Черновицкой области.

Для творческого использования опыта освещения фризического воспитания детей и молодежи в прессе Буковины выяснено фрактическое состояние публикаций в газетах Черновицкой области. Цель исследования - проанализировать статьи в современных газетах Черновицкой области для определения соответствия публикаций на физкультурно-спортивную тематику интересам населения края, для чего применен комплекс методов: общенаучные; конкретно-научные; логикосистемный анализ; эмпирические. Рассмотрены три группы газет - районные, народоведческие и областное ученическое издание и выделены основные направления физкультурно-спортивной тематики: результаты соревнований по различным видам спорта и успехи местных спортсменов («Днестровские зори», "Хотинские вести», «Вижницкие горизонты», «Ученический вестник Буковины»); популяризачия физической активности и здорового образа жизни («Голос края», «Сокиряны. Семь дней», «Хотинские вести», «Экономически-благочестивый вестник», «Здравствуйте!» и «Добрый советчик»).

Ключевые слова: Буковина, газета, дети, здоровый образ жизни, тематика, физическое воспитание, школьники. 


\section{SUMMARY}

Dariychuk Sergiy. Physical education of children and youth on the pages of modern newspapers of Chernivtsi region.

In order to creatively use the experience of covering physical education of children and youth in the Ukrainian press of Bukovyna (second half of the XIX - early XX centuries) the recommendations on systematic, thematic and content of materials on a particular topic in modern media quality of such publications in newspapers and periodicals of Chernivtsi region should be given. The purpose of the study is to analyze articles in modern newspapers of Chernivtsi region to determine the relevance of publications on physical culture and sports to the interests of the population of the region, for which a set of methods was used: general scientific; specific scientific; logical-systemic analysis; empirical. In order to determine the compliance of publications on physical culture and sports to the needs of the population of the region, three groups of newspapers were considered - district; ethnographic and regional student publications. The main directions of physical culture and sports topics of district newspapers are highlighted: results of competitions in various sports (football, athletics, wrestling, volleyball, tourism, etc.) of regional, national and international levels and successes of local athletes ("Dniester Stars", "Khotyn News", "Vyzhnytsky horizons"); history of sports movement ("Carpathians"); problems of popularization of physical activity and healthy lifestyle ("Voice of the Land", "Sokyriany. Seven Days", "Nasha Gazeta" (Our Newspaper), "Khotyn News"). Ethnographic "Economic and pious bulletin of Garafina Makova", the newspaper "Good health!" and "Good mentor" physical education of the younger generation - hardening of the body, formation of vital motor skills and abilities and health promotion, are considered through the prism of folk customs, rituals in everyday life. Among the 15 sections of the "Student Bulletin of Bukovyna" we find "Healthy Lifestyle", which combines materials that we have divided into three major common thematic areas: the success of athletes in the Chernivtsi region at competitions; aspects of the organization of health and physical culture and mass events in education institutions of the region; features of healthy nutrition of school-age children.

Key words Bukovyna, newspaper, children, healthy lifestyle, topics, physical education, schoolchildren.

\section{удк 373. 015.31:613(043.5)}

Світлана Замрозевич-Шадріна

ДВНЗ «Прикарпатський національний університет

Імені Василя Стефаника»

ORCID ID 0000-0003-0138-3587

DOI 10.24139/2312-5993/2020.10/347-355

\section{ФОРМУВАННЯ КУЛЬТУРИ ЗДОРОВ'Я ОСОБИСТОСТІ У ВІТЧИЗНЯНОМУ І ЗАРУБІЖНОМУ ДОСВІДІ}

Метою статті $\epsilon$ висвітлення окремих теоретико-прикладних аспектів формування культури здоров'я особистості у вітчизняному й зарубіжному досвіді. Для досягнення визначеної мети було використано такі методи дослідження: теоретичний аналіз педагогічної, фрілософської, психологічної літератури, нормативних документів, матеріали періодичних видань із теми дослідження. Актуалізовано необхідність вивчення проблем, пов'язаних із процесом формування культури здоров'я особистості як універсального загальнолюдського концепту. Узагальнено, що формування культури здоров'я є важливою складовою міжгалузевих 